\title{
Antikoagülan ilişkili nefropati
}

\author{
Anticoagulant-related nephropathy
}

Halil Güner, Belda Dursun, Murat Yaşar Taş

\section{Öz}

Antikoagulan ilişkili nefropati, varfarin veya diğer antikoagulan ajanlarla antikoagulasyonun neden olduğu bir tür akut böbrek hasarıdır. INR $>4$ olduğunda antikoagulan ilişkill nefropati gelişim riskinin arttı̆ı̆ı görülmektedir. Bu yazıda supraterapötik doz varfarin kullanımı sonucu akut böbrek hasarı gelişen bir olgu sunulmuştur. Atrial fibrilasyon nedeniyle varfarin kullanan, eşlik eden, obezite, hipertansiyon, tip 2 diabetes mellitus ve kronik böbrek hastalığı tanıları olan 61 yaşında erkek hasta sol böğründe şişlik ve morluk ile acil servise başvurdu. Göğüs sol posterolateral duvarında hematomu olan hastanın laboratuvar analizlerinde INR:9,7 serum kreatinin seviyesi bazal değerinin 2 katının üzerinde (bazal değeri: $3,4 \mathrm{mg} / \mathrm{dL}$, en yüksek: 6,2 mg/dL) saptandı. Hemoglobin 6,8 $\mathrm{g} / \mathrm{dL}$ 'ye kadar düştü. Varfarin kesilip INR güvenli aralığa çekilmesiyle hastanın serum kreatinini bazal düzeyine geriledi. Akut böbrek hasarı yapabilecek diğer nedenler dışlandı ve supraterapötik doz varfarin kullanımı olan hastada antikoagulan ilişkili nefropati geliştiği düşünüldü. Bu olgu komorbiditeleri fazla olan özellikle kronik böbrek hastalarında antikoagulan tedavilerin dikkatli takip gerektirdiğini göstermektedir. Antikoagulan kullanan hastalarda akut böbrek hasarı etiyolojisinde antikoagulan ilişkili nefropati akılda tutulmalıdır.

Anahtar kelimeler: Antikoagulan, varfarin, akut böbrek hasarı, kronik böbrek hastalığı.

Güner H, Dursun B, Taş MY. Antikoagülan ilişkili nefropati. Pam Tıp Derg 2021;14:518-521.

\begin{abstract}
Anticoagulant-associated nephropathy is a type of acute kidney injury caused by anticoagulation with warfarin or other anticoagulant agents. It appears that the risk of developing anticoagulant-associated nephropathy increases when INR $>4$. In this article, a case who developed acute kidney injury due to the use of a supratherapeutic dose of warfarin is presented. A 61-year-old male patient with comorbidities of obesity, hypertension, type 2 diabetes mellitus and chronic kidney disease, using warfarin due to atrial fibrillation, was admitted to the emergency room with swelling and bruising in his left flank. In the laboratory analysis of the patient who had hematoma in the left posterolateral wall of the chest, INR: 9.7 serum creatinine level was found above 2 times the baseline value (baseline value: $3.4 \mathrm{mg} / \mathrm{dL}$, the highest: $6.2 \mathrm{mg} / \mathrm{dL}$ ). Hemoglobin decreased to $6.8 \mathrm{~g} / \mathrm{dL}$. With the discontinuation of warfarin and decreaseing the INR to the safe range, the patient's serum creatinine regressed to the basal level. Other causes of acute renal injury were excluded and anticoagulant-associated nephropathy was thought to develop in the patient who used supratherapeutic dose of warfarin. This case shows that anticoagulant treatments require careful follow-up, especially in chronic kidney patients with high comorbidities. Anticoagulant-associated nephropathy should be kept in mind in the etiology of acute kidney injury in patients using anticoagulants.
\end{abstract}

Key words: Anticoagulant, warfarin, acute kidney injury, chronic kidney disease.

Guner H, Dursun B, Tas MY. Anticoagulant-related nephropathy. Pam Med J 2021;14:518-521.

Halil Güner, Arş. Dr. Pamukkale Üniversitesi Tıp Fakültesi İç Hastalıkları Anabilim Dalı, Denizli, Türkiye, e-posta: gunerhalil@hotmail.com (https://orcid. org/0000-0002-3301-7066) (Sorumlu Yazar)

Belda Dursun, Prof. Dr. Pamukkale Üniversitesi Tıp Fakültesi İç Hastalıkları Anabilim Dalı Nefroloji Bilim Dalı, Denizli, Türkiye, e-posta: belda.dursun@ gmail.com (https://orcid.org/0000-0003-3235-0577)

Murat Yaşar Taş, Uzm. Dr. Pamukkale Üniversitesi Tıp Fakültesi lç Hastalıkları Anabilim Dalı Nefroloji Bilim Dalı, Denizli, Türkiye, e-posta: mrtysrts07@ yahoo.com (https://orcid.org/0000-0003-1459-1836) 


\section{Giriş}

Antikoagulan ilişkili nefropati (AIN), varfarin ve diğer antikoagulanlara bağlı gelişen akut böbrek hasarı $(\mathrm{ABH})$ durumudur. Atriyal fibrilasyon nedeniyle varfarin ve diğer oral antikoagulan ilaçlarla antikoagulasyonu sağlanan hastalarda $\mathrm{ABH}$ önemli bir sorun olmaktadır. Varfarin kullanan ve kronik böbrek hastalığı $(\mathrm{KBH})$ olan kişilerde \%26'ya varan oranda $A B H$ gelişimi bildirilmiştir [1]. Üstelik AiN, artan mortalite riski ile ilişkilendirilmektedir [1-3]. Antikoagulan tedavi alan hasta sayısının fazla olması ve bu hastalara her gün yenilerinin eklenmesi AîN önemini artırmaktadır. Bu yazıda yüksek doz varfarin kullanımı sonucu $A B H$ gelişen bir olgu sunulmaktadır.

\section{Olgu}

61 yaşında erkek hasta sırtının sol yanında şişlik ve morluk yakınmasıyla acil servise başvurdu. Obez, 15 yıldır hipertansiyon, 11 yıldır $\mathrm{KBH}, 5$ yıldır Tip 2 diabetes mellitus, 2 yıldır atriyal fibrilasyon öyküsü olan hastanın $5 \mathrm{mg}$ varfarin yanı sıra $300 \mathrm{mg}$ allopurinol, $4 \mathrm{mg}$ doksazosin, $40 \mathrm{mg}$ furosemid, $600 \mathrm{mg}$ gemfibrozil, 12,5 mg karvedilol kullanımı mevcuttu. Varfarin doz düzenlemesi için kardiyoloji polikliniğinde yakın INR takibi önerildiği ancak hastanın buna uymadığı öğrenildi. Fizik muayenede bilinci açık, oryante, koopere, solunum sesleri olağan, kardiyovasküler sistem muayenesi olağan, batın muayenesi olağan saptandı. Sol aksillada ekimoz, sol skapula lateralinde $10-15 \mathrm{~cm}$ boyutlarında, yeni gelişen şişliği mevcuttu. Vital bulguları kan basıncı 140/90 mmHg, nabız:90 atım/dk, ss:20/dk, oksijen saturasyonu: \%96 idi. Laboratuvar tetkiklerde serum üre: $135 \mathrm{mg} / \mathrm{dL}$, serum kreatinin:6,2mg/dL, hemoglobin:7,5 g/ $\mathrm{dL}$, INR:9,7 saptandı. Bazal serum kreatinini 3,4 $\mathrm{mg} / \mathrm{dL}$ olan hasta $\mathrm{KBH}$ zemininde gelişen $\mathrm{ABH}$ nedeniyle hospitalize edildi. Bazal hemoglobin değeri 10,8 $\mathrm{g} / \mathrm{dL}$ olan ve takibinde hemoglobin $6,8 \mathrm{~g} / \mathrm{dL}$ 'ye kadar düşen hastaya 3 gün içinde toplam 4 ünite eritrosit süspansiyonu verildi. Çekilen tomografide göğüs sol posterolateral duvarında $17 \times 7 \mathrm{~cm}$ boyutlu hematom saptandı. Renal ultrasonografi normal saptandı. Varfarin kesildi ve INR monitorizasyonuna başlandı. Takibinde INR 1,2 düzeyine kadar geriledi. INR değerinin güvenli aralığa çekilmesiyle birlikte hastanın günler içerisinde kademeli olarak serum kreatinin değerinde gerileme izlendi (Grafik 1). Bu arada hastada enfeksiyon hipovolemi, nefrotoksik ajan ya da kontrast maruziyeti gibi $\mathrm{ABH}$ etiyolojisinde yer alan nedenler dışlandı. Supraterapötik doz varfarin kullanımı olan hastada AîN geliştiği düşünüldü. Hematoma yönelik göğüs cerrahisi hematom boşaltımı önermedi ve spontan rezolüsyonu

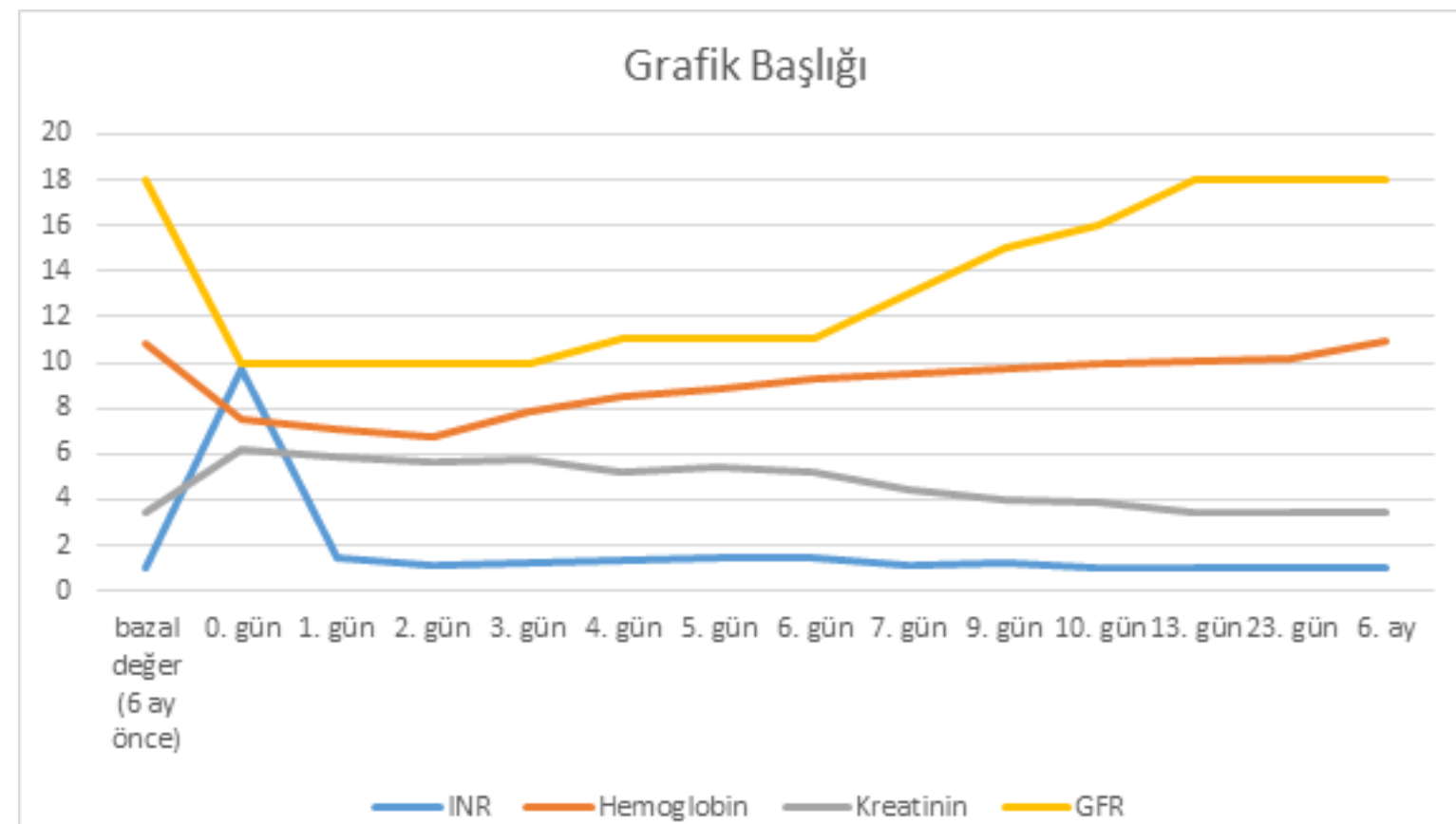

Grafik 1. Olgunun takibinde INR, hemoglobin, kreatinin ve GFR değişimleri görülmektedir 
izlendi. Kontrol toraks BT de hematomda küçülme görüldü. Serum kreatinin geriledi ve izlemde bazal düzeyi olan $3,4 \mathrm{mg} / \mathrm{dL}$ civarında seyretti. Bu süreçte $300 \mathrm{mg}$ asetilsalisilat ile takip edildi. Takibinde düşük doz antikoagulasyon ve düşük molekül ağırlıklı heparinizasyon için tekrar değerlendirilmesi planlandı.

\section{Tartışma}

Antikoagulanla ilişkili nefropati (AIN), varfarin veya diğer antikoagulan ajanlarla antikoagulasyonun neden olduğu bir tür akut böbrek hasarıdır $(\mathrm{ABH})$ [1]. AîN için ana risk faktörü, varfarin veya diğer antikoagulanlar tarafından indüklenen orta veya şiddetli antikoagulasyondur. INR $>4$ olduğunda AIN gelişim riskinin arttığı görülmektedir. Diğer risk faktörleri altta yatan kronik böbrek hastalığı $(\mathrm{KBH})$, diabetes mellitus, kalp yetmezliği, hipertansiyon ve glomerülonefrit, özellikle nefrotik sendromdur [3-5]. Böbrek biyopsisi ile histopatolojik analiz ve hayvan modellerinde yapılan çalışmalar sonucunda patogenezi başlatan olay, aşırı antikoagulasyonun neden olduğu glomerüler kanama gibi görünmektedir [2]. Glomerüler kanama, eritrosit silendirleri ile renal tübüllerde tıkanmaya, renal tübül içerisinde eritrofagositoz sonrası hemoglobinin yıkıma uğraması sonucu açığa çıkan hem ve demirin oksidasyonu ile de doğrudan tübüler hasara yol açmaktadır [6, 7]. Hastalar anormal derecede yükselmiş INR sonucu birkaç gün içinde (genellikle bir hafta içinde) $\mathrm{ABH}$ ile başvururlar. Mikroskopik ve daha az yaygın olarak, makroskopik hematüri olabilir. Hematüri geçici olabilir; ancak, başvuru anında hematüri olmaması AîN olasılığını dışlamak için yeterli değildir. Görüntülemede karakteristik bir özellik yoktur ve böbrek ultrasonografisi normaldir [35]. Anlatılan olguda başvuru anında ve takibinde hematüri izlenmedi ve böbrek ultrasonografisi normaldi.

$A B H$ ve supraterapötik dozda varfarin birlikte (INR>4) görülen hastalarda AiN tanısı akla gelmelidir. Kesin tanı renal biyopsi ile konur. Ancak, biyopsi en azından başlangıçta antikoagulan tedavi alan hastalarda kanama riski yüksek olduğu için genellikle yapılmaz. Literatürde biyopsi yapıldığı bildirilen vakalarda ise histolojik olarak glomerüler hemoraji görülmektedir [4]. ABH'nin diğer nedenleri klinik özellikler ve laboratuvar testleri ile dişlanan bir hastada, şiddetli bir pıhtılaşma bozukluğu varsa veya yakın zamanda saptanmış ise AiN teşhisi konulabilir. Anlatılan olguda da $\mathrm{ABH}$ yapabilecek diğer nedenler dışlandıktan sonra başvuru anında INR 9,7 olması ve koagulopatinin düzelmesiyle kreatinin değerinin gerilemesi tanı koydurucu olmuştur. Ayrıca olgunun tip 2 diyabetes mellitus, hipertansiyon, obezite, $\mathrm{KBH}$ gibi komorbiditelere sahip olması AîN gelişimini riskini arttırmıştır. Koagulopatinin düzeltilmesinden sonra serum kreatinin artmaya devam ederse veya bazal seviyenin üzerinde önemli ölçüde yükselmiş kalırsa, kesin tanı için bir biyopsi gerekebilir [5, 8]. AíN'yi önlemede en önemli olan antikoagulan dozun doğru ayarlanmasıdır. Bu, AîN'ye daha yatkın olan $\mathrm{KBH}$ olan hastalar için özellikle önemlidir.

Tedavide ise INR'nin terapötik ve güvenli aralığa getirilmesi esas olup $\mathrm{ABH}$ tedavisinin genel ilkeleri de eş zamanlı uygulanmalıdır. Sunulan olgu örneğinde olduğu gibi hastaların çoğunda, serum kreatinin, varfarin koagulopatisinin düzeltilmesinden sonraki ilk birkaç hafta içinde hafifçe stabilize olur veya iyileşir. Bununla birlikte, bazı hastalarda böbrek fonksiyonlarının iyileşmesi çok az veya hiç olmayabilir. Ancak atriyal fibrilasyon sıklığı ve giderek artan sayıda hastanın antikoagulan tedavi altında olması AIN önemini artırmaktadır. Özellikle $\mathrm{KBH}$ olan hastalarda antikoagulan tedavilerin yakın takibi ve hasta uyumu oldukça önemlidir. ABH ile gelen hastalarda antikoagulan kullanımı durumunda AiN etiyolojide akılda tutulmalıdır.

Çıkar ilişkisi: Yazarlar çıkar ilişkisi olmadığını beyan eder.

\section{Kaynaklar}

1. Bansal N, Xie D, Tao K, et al. Atrial fibrillation and risk of ESRD in adults with CKD. Clin $\mathrm{J}$ Am Soc Nephrol 2016;11:1189-1196. https://doi.org/10.2215/ CJN.10921015

2. Ryan M, Ware K, Qamri Z, et al. Warfarin-related nephropathy is the tip of the iceberg: direct thrombin inhibitor dabigatran induces glomerular hemorrhage with acute kidney injury in rats. Nephrol Dial Transplant 2014;29:2228. https://doi.org/10.1093/ndt/gft380

3. Brodsky SV, Nadasdy T, Rovin BH, et al. Warfarinrelated nephropathy occurs in patients with and without chronic kidney disease and is associated with an increased mortality rate. Kidney Int 2011;80:181. https://doi.org/10.1038/ki.2011.44 
4. Brodsky SV, Satoskar A, Chen J, et al. Acute kidney injury during warfarin therapy associated with obstructive tubular red blood cell casts: a report of 9 cases. Am J Kidney Dis 2009;54:1121. https://doi.org/10.1053/j. ajkd.2009.04.024

5. Brodsky SV, Collins M, Park E, et al. Warfarin therapy that results in an International normalization ratio above the therapeutic range is associated with accelerated progression of chronic kidney disease. Nephron Clin Pract 2010;115:142. https://doi. org/10.1159/000312877

6. Ware K, Brodsky P, Satoskar AA, et al. Warfarinrelated nephropathy modeled by nephron reduction and excessive anticoagulation. J Am Soc Nephrol 2011;22:1856. https://doi.org/10.1681/ ASN.2010101110

7. Schützer KM, Svensson MK, Zetterstrand S, Eriksson UG, Wåhlander K. Reversible elevations of serum creatinine levels but no effect on glomerular filtration during treatment with the direct thrombin inhibitor AZD0837. Eur J Clin Pharmacol 2010;66:903. https:// doi.org/10.1007/s00228-010-0849-7

8. An JN, Ahn SY, Yoon $\mathrm{CH}$, et al. The occurrence of warfarin-related nephropathy and effects on renal and patient outcomes in korean patients. PLoS One 2013;8:e57661. https://doi.org/10.1371/journal. pone.0057661

Hasta onamı açıklaması: $\mathrm{Bu}$ olguda antikoagulan ilişkili nefropati tanısına meslektaşlarımızın dikkatini çekmek amaçlanmıştır. Bu amaçla hastamızın tanı ve tedavi süreci ile ilgili bilgiler verilmiştir. Hastamızın kimlik bilgileri ya da fotoğrafı kullanılmamıştır. Hasta üzerinde bir deneysel çalışma yapılmamıştır. Dolayısıyla hasta onamı gerektirecek bir durum oluşmamıştır.

Bu olgu 19-21 Nisan 2018 tarihinde 7. Güncel Böbrek Hastalıkları, Hipertansiyon ve Transplantasyon Toplantısı'nda poster olarak sunulmuştur.

\section{Yazarların makaleye olan katkıları}

B.D. çalışmanın ana fikrini ve hipotezini kurgulamıştır. Makalenin tartışma bölümü H.G. tarafından yazılmış, M.Y.T. ve B.D. gözden geçirip gerekli düzeltmeleri yapmış ve onaylamıştır. Ayrıca tüm yazarlar çalışmanın tamamını tartışmış ve son halini onaylamıştır. 